\title{
Seasonal incidence of major sucking pests infesting cowpea and their relation to weather parameters
}

\author{
T. Anandmurthy ${ }^{1}$, G. M. Parmar* and G. Arvindarajan ${ }^{1}$
}

Millet Research Station (J.A.U.), Jamnagar (Gujarat) India

${ }^{1}$ Department of Entomology, Junagadh Agriculture University, Junagadh (Gujarat) India

\section{ARITCLE INFO}

Received : 25.12 .2017

Revised : 06.03 .2018

Accepted : 14.03 .2018

\section{KEY WORDS :}

Sucking pests, Cowpea

weather parameters
*Corresponding author:

dr.gmparmar@rediffmail.com

\begin{abstract}
Investigations were carried out on seasonal incidence of major sucking pests that attack the cowpea at College Farm, Junagadh Agricultural University, Junagadh during summer 2016. The result revealed that jassid population initiated from the second week of March with 0.48 nymph/ 3 leaves/ plant and reached a peak (4.91 nymphs/ 3 leaves/ plant) in first week of May. The population of whitefly and aphid also appeared from the second week of March and reached to a peak of 4.99 whiteflies/ 3 leaves/ plant and 3.82 aphid index / plant during the fifth week of April, respectively. Among the various weather parameters, maximum temperature showed a significant positive correlation with jassid, whitefly and aphid population in summer cowpea. Whereas, wind speed showed negative influence and bright sunshine hours exhibited positive influence on population of all sucking pests in cowpea crop.
\end{abstract}

How to view point the article : Anandmurthy, T., Parmar, G.M. and Arvindarajan, G. (2018). Seasonal incidence of major sucking pests infesting cowpea and their relation to weather parameters. Internat. J. Plant Protec., 11(1) : 35-38, DOI : 10.15740/HAS/IJPP/11.1/35-38. 